\title{
A NOTE ON GEORGE GISSING
}

\section{ARTHUR C. YOUNG}

On May 6, I899, George Gissing sailed from England on the channel boat for Dieppe en route to Rouen where he was to meet Mlle. Gabrielle Fleury and her mother at the Hôtel de Paris. The rendezvous had been carefully planned on Gissing's part for it had meant a decision to leave England permanently and to separate himself from his two sons, Alfred and Walter. Although he had not lived with his wife Edith since I 897, he nevertheless kept informed about her actions and the welfare of young Alfred, who was still in his mother's custody. Walter, the elder of the two boys, was safely out of the way of his strepitant mother at a small school in Wakefield, run by Gissing's sisters, Margaret and Ellen. Yet as disturbed as Gissing was about leaving England and his sons, he was still more nervous about the purpose of his trip: without having obtained a divorce from Edith, he planned to marry Gabrielle Fleury and re-establish a home in France. He and Gabrielle Fleury went through an illegal ceremony on May $7,1899,{ }^{1}$ but in their own minds and in the eyes of their friends, the union was permanent and binding.

Now in the Special Collections of the Rutgers University Library is a photostat of a post card which Gissing sent to F. G. Kitton, with whom he was collaborating on a new edition of Dickens's works, scheduled for publication by Methuen and Company. The post card, dated 7 May I 899, is interesting for two reasons: it not only shows the equilibrium of Gissing's mind on a day during which he might well be excused for being unnerved, but it also indicates the respect which Kitton, who had been appointed to write the notes for the Dickens edition, held for his collaborator.

The card, addressed to F. G. Kitton Esq. / Pré Mill House / St. Albans / Angleterre, reads as follows:

\footnotetext{
${ }^{1}$ Mabel C. Donnelly, George Gissing: Grave Comedian (Harvard University Press, I954), p. 193 .
} 
Herewith I return the notes-grieved at the delay, occasioned by my departure. Hope it is not material. Notes admirable! Do not see how they could now be possibly improved.

Safest address in future:

$$
\begin{gathered}
\text { c/o J. B. Pinker Esq. } \\
\text { Effingham House } \\
\text { Arundel St. } \\
\text { Strand. W. C. }
\end{gathered}
$$

Hope you have such glorious weather as has set in over here!

$$
\text { Yours, }
$$

Hôtel de Paris.

G. Gissing

Rouen.

May 799.

Gissing had been engaged by Methuen and Company to write the prefaces for the new edition of Dickens early in I 898, probably because of the success of his Charles Dickens-A Critical Study, published by Blackie \& Son in I 898. By March I3, I 899, he had completed six prefaces, ${ }^{2}$ and then wrote six more. Unfortunately, the new edition, which was called the "Rochester Edition," was a financial failure, and after six volumes were printed, the whole project was given up.

Since Kitton was not a close friend, there was no need to explain the trip to France, and the request that mail in the future be sent to J. B. Pinker, a literary agent, shows that Gissing did not intend to reveal the details of his personal life. The notes mentioned in the message were those which Kitton had prepared for the first volume, and which Gissing apparently had taken with him to read while traveling to Rouen.

2 A.L.S., George Gissing to Eduard Bertz, 13 May I 899, Yale University Library. 